\title{
Ant species diversity in ciliary forest and gallery forest areas in central Brazil
}

\author{
João Augusto Vieira de Oliveira*, Daiane Martins da Silva, Flávia Assumpção Santana \\ Unidade Universitária, Universidade Estadual de Goiás, Quirinópolis, Brazil; *Corresponding Author: j.augustooliveira@live.com
}

Received 25 June 2013; revised 19 August 2013; accepted 1 September 2013

Copyright (C) 2014 João Augusto Vieira de Oliveira et al. This is an open access article distributed under the Creative Commons Attribution License, which permits unrestricted use, distribution, and reproduction in any medium, provided the original work is properly cited. In accordance of the Creative Commons Attribution License all Copyrights (C) 2014 are reserved for SCIRP and the owner of the intellectual property João Augusto Vieira de Oliveira et al. All Copyright (C) 2014 are guarded by law and by SCIRP as a guardian.

\section{ABSTRACT}

Ants make up an important group of insects of the Cerrado in terms of biomass, number of individuals, and ecological impact. The main goals of this study were to quantify the species richness and species diversity of the family Formicidae in two riparian Cerrado physiognomies: Ciliary Forest and Gallery Forest, and to evaluate the effectiveness of two collection techniques for these organisms. The study was conducted during the dry season, comprising the months of May to October 2012, in the municipality of Quirinópolis, Goiás State, Brazil. Samples were made using two capture techniques: sardine baits and pitfall traps. Manual collection was employed to extend the range of faunistic composition of the ants. We collected 24 species of ants in the Gallery Forest and 23 in the Ciliary Forest. The genus Megalomyrmex was the most representative, being present in $49.46 \%$ of the samples, and secondly the genus Pheidole, with $15.36 \%$ of the total individuals captured. From a total of 10,917 individuals, 9140 were captured using the bait technique, 1738 with traps, and 39 individuals through manual collection. Similar results were found in the Cerrado of Paineiras, with $\mathbf{4 5}$ ant species distributed in $\mathbf{1 6}$ genera belonging to 5 subfamilies.

\section{KEYWORDS}

Species Richness; Formicidae; Cerrado; Pitfall; Sardine Bait Traps

\section{INTRODUCTION}

Ants have characteristics relevant to the study of bio- diversity, such as plasticity, high diversity, numerical and biomass dominance in various habitats, ease of sampling, as well as the presence of stationary nests, allowing resampling over time [1]. They are excellent seed dispersers influencing the processes of forest regeneration [2], modifying the seed deposition generated by primary dispersers, and influencing the spatial distribution of plant populations, thus a number of species can be considered ecosystem engineers [3]. They are organisms tightly linked to the nitrogen cycle, making nitrogen available for consumption by plant species, in addition to their prominent role as decomposers of organic matter [4]. Due to this tight linkage with vegetation, they are highly sensitive to environmental variations, and are considered excellent bioindicators of an ecosystem [4].

Factors such as nesting sites, trunk roughness, and specific food resources such as extrafloral nectaries and sugar-rich hemipteran excreta, make areas of the Cerrado biome, including its phytophysiognomies (Ciliary Forests, Gallery Forests, Dry Forest, and Cerradão (xeromorphic forest), sites of great importance for the study of ant fauna. These species are highly adapted to foraging and nesting in plants, thus suggesting a high richness of ants in these areas [5].

The Cerrado occupies $21 \%$ of the national territory, representing the second largest biome in Brazil, surpassed only by the area in Amazon forest [6]. Cerrado is a markedly heterogeneous vegetation, resulting from interactions of biotic and abiotic parameters that determine quantitative (species presence/absence) and qualitative (abundance) aspects of its vegetation. It consists of various vegetable species originating in the temporal variation of factors such as climate and geomorphology [7].

Studies suggest that the Cerrado presents an invertebrate species richness of around 90,000 species [8]. On the other hand, the creation of conservation policies has been much more limited than those decreed for the Ama- 
zon or the Atlantic Forest, since only 2.2\% of the biome is legally protected, while it is estimated that at least $20 \%$ of the biome's endemic and threatened species remain outside of conservation areas [9].

Despite its importance, approximately 55\% of the Cerrado has already been cleared or transformed by human action, which is equivalent to almost three times the area deforested in the Brazilian Amazon. Deforestation rates range between 22,000 and $30,000 \mathrm{~km}^{2}$ per year [10]. Such deforestation is mainly due to population growth in Central Brazil, agricultural expansion, mineral extraction, charcoal production and burning practices. This is causing a major fragmentation of habitats which is leading to species local extinction and alterations in the trophic interactions [11]. These facts led to the Cerrado's designation as a Hotspot (areas of the Earth with high biodiversity that are under a high degree of threat) [12].

The surveys of ants in this biome are still rare, which limits the understanding of Formicidae species richness in this ecosystem [13-15]. Considering the major importance of the Cerrado in terms of fauna diversity, the aim of this study was to obtain the richness and diversity of ant species in two Brazilian Cerrado forest types (Ciliary Forest and Gallery Forest) and evaluate the effectiveness of two techniques for collecting ants in these areas.

\section{MATERIAL AND METHODS}

\subsection{Study Area}

The study was conducted between May and October 2012, comprising the dry season and the transition to the rainy season, near the Douradinho Farm, $30 \mathrm{~km}$ from the city center of Quirinópolis in the State of Goiás, Brazil (South-18.437507, West-50.664171, with an average altitude of $494 \mathrm{M}$ ) (Figure 1).

According to the Köppen classification system, the climate of the region is type Aw, megathermal with two seasons best defined as: a dry season (April to September) and a rainy season (October to March), in which the average temperature ranges from lower in the dry season to higher in the summer rainy season [17]. The study area is currently undergoing a process of anthropization through cattle ranching and from a highway, both bordering on the physiognomies analyzed, as shown in Figure 2.
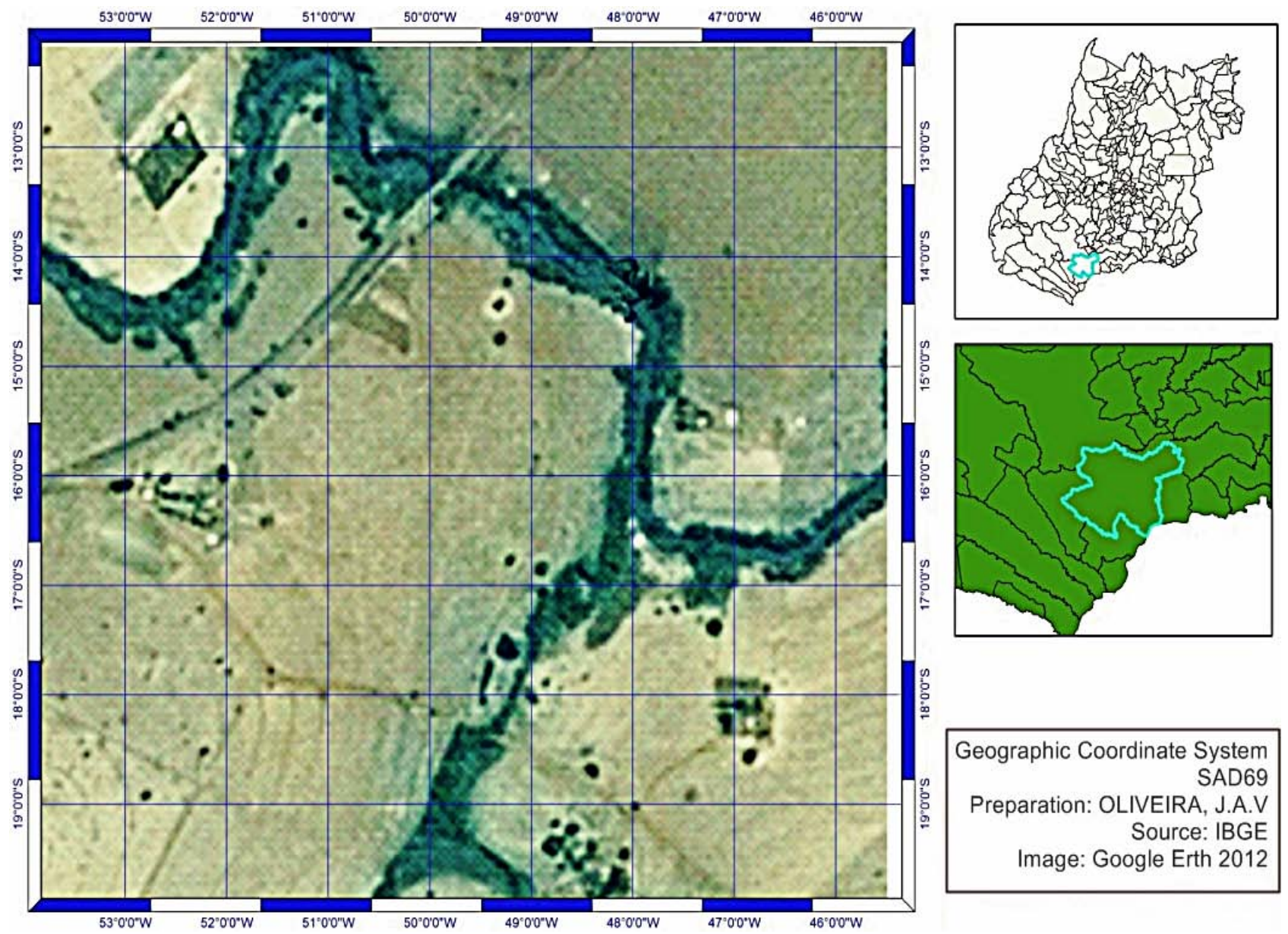

Figure 1. Map representing the field sampled, Douradinho Farm—Quirinópolis, Goiás—Brazil (ArcGIS 9—ArcMap version 9.3) [16]. 


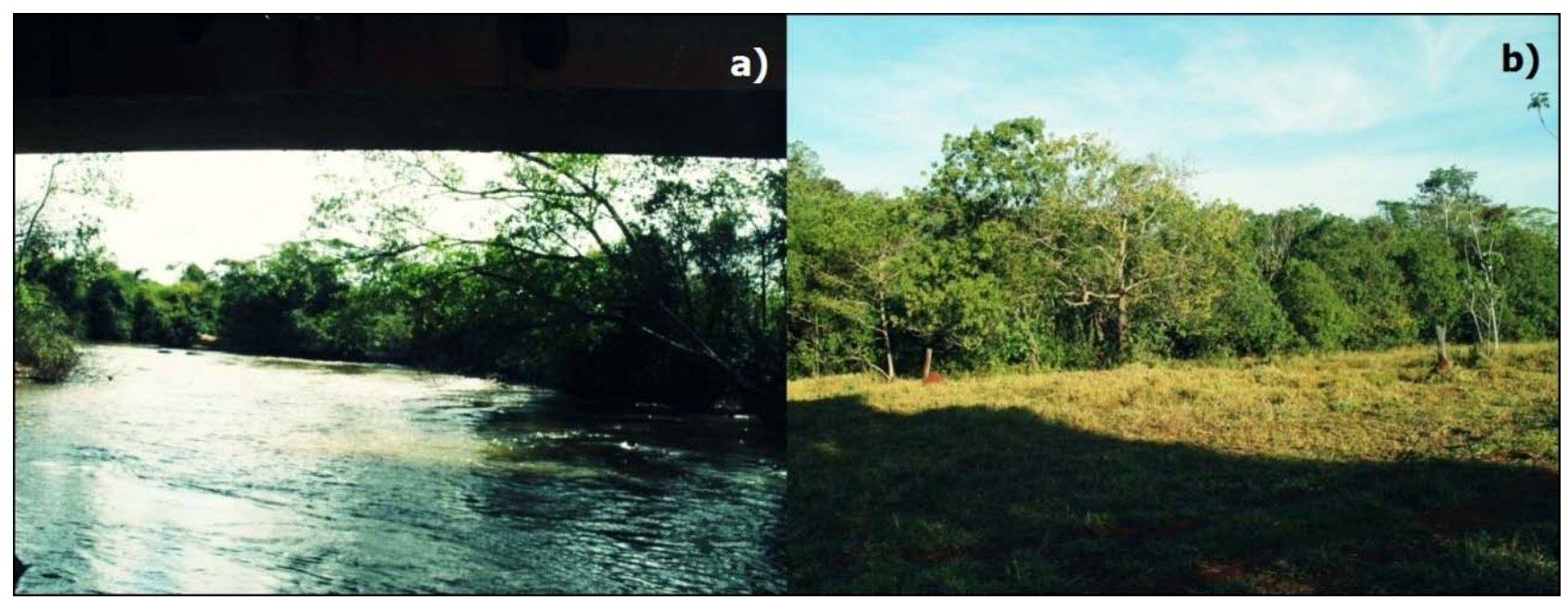

Figure 2. Study area. (a) Ciliary forest; (b) Gallery forest—Douradinho Farm, Quirinópolis, Goiás—Brazil.

\subsection{Ant Sampling}

Sardine trap-sardine was used, which was ground together with its oil and placed on white paper, in $15 \times$ $10 \mathrm{~cm}$ sheets. Five bait traps were placed in each of the four transects of the Gallery Forest (GF) and the same number for the Ciliary Forest (CF) (Figure 3). Each transect covered approximately twenty-five meters, opened at points staggered from one another by one hundred meters, and the bait traps were placed in the soil with a distance between them of about five meters. These were left in the ground for 60 minutes, to carry out the recruitment period. Samples were collected mainly in the morning and the afternoon/evening, always being shut down at dusk. The ants were then collected using entomological forceps or brushes, and preserved in vials with $70 \%$ alcohol.

Pitfall traps-this technique consisted of capturing ants using PET bottles approximately $10 \mathrm{~cm}$ in diameter, cutting off the upper portions and planting the bases in the ground to an average depth of $10 \mathrm{~cm}$. Within the traps, we placed water with about three drops of neutral detergent to reduce surface tension, which ensured greater efficiency in the capture. A set of five traps with five meters of separation were arranged among the transects of the sardine traps (Figure 3). This type of trap remained exposed in both physiognomies for approximately 24 hours. After this period they were withdrawn, and ant species were sorted using forceps at the actual collection site, and were preserved in vials with $70 \%$ alcohol, (Figure 3).

\subsection{Identification and Statistical Analysis}

The captured ant species were sent to the laboratory at the State University of Goiás, Quirinópolis Campus. In the laboratory, the samples were separated and identified to genus level, with the keys found on the websites [18,
19] and were stored under refrigeration to ensure preservation of the organisms. The ants were deposited in the Zoology laboratory at this campus, and are available for possible consultations or studies. The statistical analyses and ecological assessments were obtained using the Shannon estimator, well-suited for an analysis of ant communities to compare different areas [20], as calculated by the Biodiversity Professional Program [21]. We used species accumulation curves (collectors curve) calculated with Estimates 8.2 [22] based on the addition of new species as a function of sampling effort, including all the sampling methods. Species richness was also estimated using the Jackknife 2 estimator with a 95\% confidence interval.

\section{RESULTS AND DISCUSSION}

A total of 10,917 ants were collected, with 24 species found in the GF and 23 in the CF, and belonging to 6 subfamilies (Table 1); 9140 individuals were caught with the bait trap technique, while 1738 with pitfall traps, and 39 individuals through manual collection. Similar results were found in the Cerrado of Paineiras, MG [23], with 45 ant species distributed in 16 genera belonging to 5 subfamilies in an environment characterized by the presence of two types of vegetation (cerrado and eucalyptus monocultures).

Megalomyrmex sp1 was the species most representative in abundance, with 5400 individuals collected (49.46\%), followed by Pheidole with 1677 ants (15.36\%), and Wasmmania sp1 with 1393 (12.76\%) of the total number of individuals captured (see Table 1).

Megalomyrmex sp1 constituted almost 50\% of all the individuals captured. The genus Megalomyrmex is recognized as a nest parasite of several species of the Attini tribe. Megalomyrmex has 31 described species generally found in humid and subtropical forests of South and 


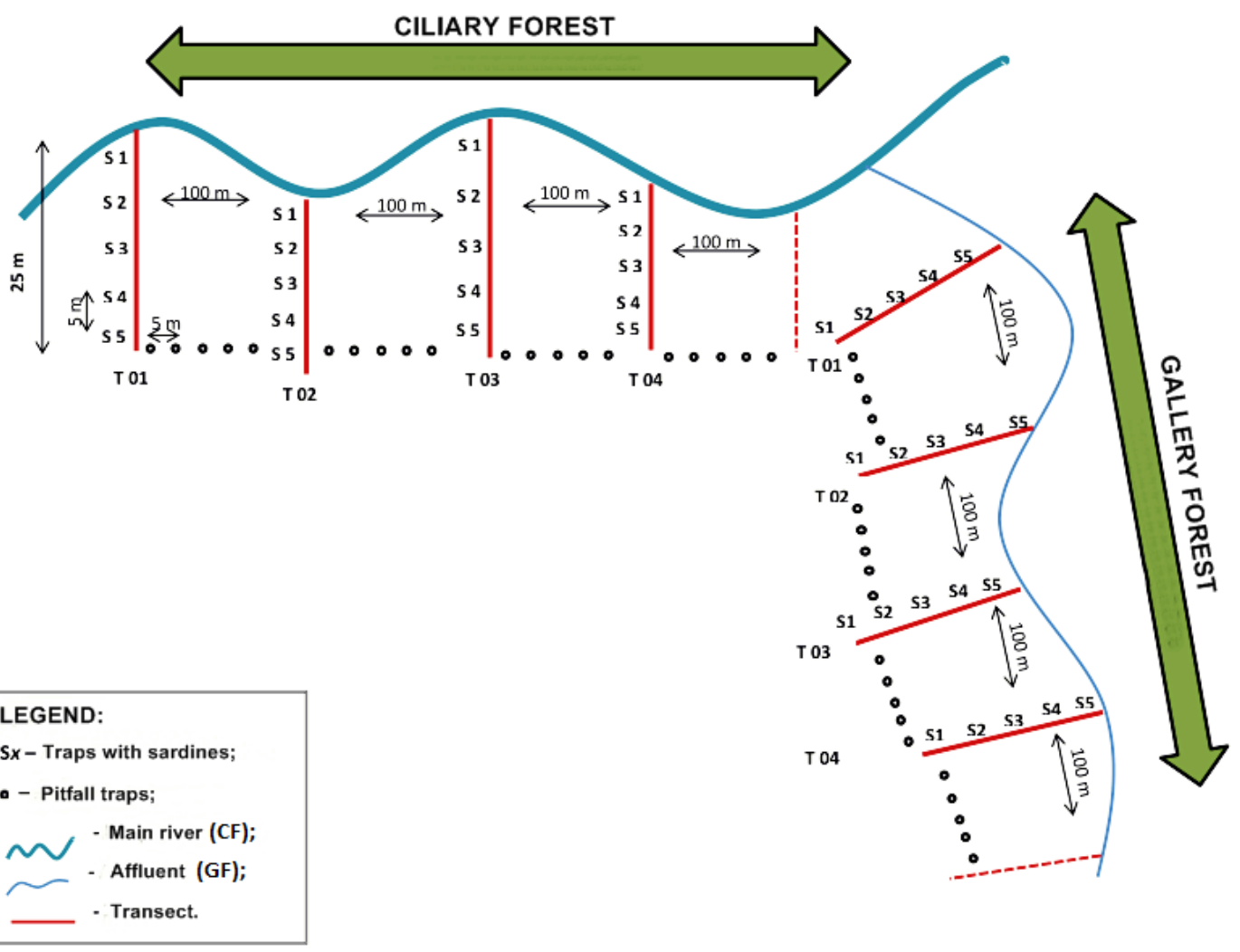

Figure 3. Schematic illustration of the capture methodology used in collecting ants in the stretches of Ciliary Forest and Gallery Forest at the Douradinho Farm, Quirinópolis, Goiás (Brazil). In addition to the two modes of collection presented, active collection was included, which consisted of capturing ants that were close to the traps, using entomological forceps.

Central America [24,25].

The genus Camponotus was the most diverse, presenting 9 morphospecies with abundance of 1096 individuals, which corresponded to $10.04 \%$ of the total sample. Pheidole sp. with 4 morphospecies, and Pachycondyla sp. and Ectatomma sp. with 3 morphospecies each, altogether corresponded to $59.37 \%$ of the sampled species. The higher number of species among the Camponotus and Pheidole genera is due to the wide distribution of these groups around the globe, with the latter being prevalent in environments with plant litter, characteristic of the two studied physiognomies [26,27]. Other studies have obtained similar results [28-31]. Of the 32 species in the CF and GF, nine (28\%) were represented by a single record among the two sample types (sardine bait and pitfall), being respectively five individuals for $\mathrm{CF}$ and four for GF.

The species represented by a single record amount to approximately $1 / 3$ of the species collected, this result leading us to believe that they are rare in these locations and have, therefore, a lower abundance than the other ants in this study. Other studies in Neotropical regions indicate a high incidence of rare ant species in one community [32,33].
The subfamily Myrmicinae was the most representative in the samples, since the three most common morphospecies belong to this taxon. The observed results confirm the representativeness of these subfamilies that are typically more numerous in leaf litter than Formicinae and Dolichoderinae [15,34-36]. This representativeness is also observed in the studies conducted in vegetation types such as Semideciduous Seasonal Forest in the Brazilian Atlantic Forest biome [29], and in Northern Minas Gerais, a region located in the transition between the Caatinga and the Cerrado biomes [30].

Myrmicinae is considered the most diverse subfamily worldwide [37]. More than $45 \%$ of the species and 52\% of the genera of Formicidae belong to this subfamily [38]. The large predominance of this taxon is due to the diversification of feeding and nesting habits, since this indicates omnivorous or generalist feeder species, notable among these are predatory individuals, consumers of liquids and fungi [39].

\subsection{Data Analysis}

Effectiveness of the sampling techniques

A crucial point in defining the richness of ants species in one location is in the means of collection. A certain 
Table 1. Ants collected in two fragments of Ciliary Forest and Gallery Forest at the Douradinho Farm, Quirinópolis, Goiás, Brazil.

\begin{tabular}{|c|c|c|c|c|c|c|c|c|c|}
\hline \multirow[b]{2}{*}{ Subfamily } & \multirow[b]{2}{*}{ Richness } & \multirow[b]{2}{*}{ Species } & \multicolumn{3}{|c|}{ GALLERY FOREST } & \multicolumn{3}{|c|}{ CILIARY FOREST } & \multirow[b]{2}{*}{ Abundance } \\
\hline & & & Baits & Pitfall & Manual & Baits & Pitfall & Manual & \\
\hline \multirow[t]{2}{*}{ Dolichoderinae } & & Dolichoderus sp1 & 1 & - & - & 27 & - & - & 28 \\
\hline & & Ectatommapermagnum (Forel) & 7 & - & - & 12 & 1 & - & 20 \\
\hline \multirow[t]{6}{*}{ Ectatomminae } & & Ectatomma sp1 & 7 & 23 & 1 & - & - & - & 31 \\
\hline & & Ectatomma sp2 & - & 4 & 1 & - & - & - & 5 \\
\hline & & Camponotusconsobrinus (Erichson) & 2 & 44 & - & 9 & 3 & - & 58 \\
\hline & & Camponotusaegaeus (Emery) & - & - & - & 6 & - & - & 6 \\
\hline & & Camponotusfestinatus (Bukley) & - & - & - & - & 1 & - & 1 \\
\hline & & Camponotuspennsylvanicus (De Geer) & 59 & - & - & - & - & - & 59 \\
\hline \multirow[t]{10}{*}{ Formicinae } & & Camponotus sp1 & - & 4 & 1 & 56 & 2 & - & 63 \\
\hline & & Camponotus sp2 & - & 1 & - & 221 & - & - & 222 \\
\hline & & Camponotus sp3 & - & 27 & - & - & - & - & 27 \\
\hline & & Camponotus sp4 & 132 & - & - & - & - & - & 132 \\
\hline & & Camponotus sp5 & - & - & - & 528 & - & - & 528 \\
\hline & & Atta sp1 & 14 & 12 & - & 4 & 449 & 22 & 501 \\
\hline & & Cephalotesminutus (Fabricius) & 131 & - & - & 389 & 7 & - & 527 \\
\hline & & Crematogasterlaeviuscula (Mayr) & 67 & - & - & - & - & - & 67 \\
\hline & & Megalomyrmex sp1 & 1642 & 410 & - & 2651 & 697 & - & 5400 \\
\hline & & Pheidolebilimek (Mayr) & - & - & - & 22 & - & - & 22 \\
\hline \multirow[t]{8}{*}{ Myrmicinae } & & Pheidoleobtusopinosa (Pergande) & 4 & - & - & - & - & - & 4 \\
\hline & & Pheidolepallidula (Nylander) & - & 4 & - & - & 2 & - & 6 \\
\hline & & Pheidole sp1 & 335 & - & - & 1310 & - & - & 1645 \\
\hline & & Wasmannia sp1 & 1374 & 14 & - & 5 & - & - & 1393 \\
\hline & & Zacryptocerusclypeatus (Fabricius) & - & - & - & 1 & - & - & 1 \\
\hline & & Zacryptocerus sp1 & - & - & - & - & - & 7 & 7 \\
\hline & & Hypoponera sp1 & - & - & - & - & 1 & - & 1 \\
\hline & & Odontomachusbauri (Emery) & 1 & 1 & 2 & 1 & 4 & - & 9 \\
\hline \multirow{4}{*}{ Ponerinae } & & Odontomachus sp1 & - & 1 & - & - & - & - & 1 \\
\hline & & Pachycondylaimpressa (Roger) & 111 & 4 & 2 & 2 & - & - & 119 \\
\hline & & Pachycondylaobscuricornis (Emery) & 1 & 2 & - & - & - & - & 3 \\
\hline & & Pachycondylavillosa (Fabricius) & - & - & - & 4 & - & 3 & 7 \\
\hline \multirow{2}{*}{ Pseudomyrmecinae } & & Pseudomyrmexsalvini (Forel) & 2 & 2 & - & 1 & - & - & 5 \\
\hline & & Pseudomyrmex sp1 & - & 18 & - & 1 & - & - & 19 \\
\hline 6 & 32 & & 3890 & 571 & 7 & 5250 & 1167 & 32 & 10,917 \\
\hline
\end{tabular}

difficulty exists in comparing these different procedures, mainly in their quantitative aspects, leading to the conclusion that each technique samples a different set of species [40]. Which, in turn, clarifies the need to use various sampling methods in order to properly estimate the richness in a particular study area.

Regarding the effectiveness of the sampling methods and the occurrence of species, it was possible to observe the following patterns: in the CF, 6449 individuals were collected, corresponding to $59 \%$ of the total ants captured in the survey, the case being that $11(48 \%)$ of the 23 species found in the CF were collected only with sardine traps, while three (13\%) were found only in pitfall traps, and one (4\%) in manual collection, and lastly eight (35\%) species were found in more than one type of trap. Most of the sample ant species in the CF, 5250 (81\%) were captured using sardine traps, 1167 (18\%) by means of pitfall traps, and the remaining $32(\sim 0.5 \%)$ through manual collection.
Whereas in the GF, 4468 individuals were collected, corresponding to $41 \%$ of the sample total, in this case eight (33\%) of the 24 species were collected only with sardine bait, five (21\%) by pitfall traps, while no species were captured solely by manual collection and 11 (46\%) species were captured by more than a single type of trap. Of the 4468 individuals collected in GF, 3890 (87\%) were caught with sardine baits, characterized by generally attracting most of the ant subfamilies, tribes, and genera, with the exception of army ants (subfamily Ecitoninae) and leafcutter ants [3]. While 571 (13\%) were collected using pitfall traps, and only seven $(\sim 0.2 \%)$ through manual collection.

In both forests the most effective technique was the sardine bait trap, which may be explained by the heightened perception of ants attracted by the characteristic odor of sardines, a factor lacking in the pitfall technique. Another negative point regarding pitfall collection lies in the ability that certain ants (usually the small ones) have 
moving along the inside of the bottle without even touching the water, which was observed several times during the course of the study. A relevant fact in relation to the use of the pitfall is the period in which the trap remains exposed in the ground (approximately 24 hours), which allows for the capture of ants with different periods of activity, as well as species that are not attracted by sardines or another attractor that could be used as bait.

It can be observed that in the records with large quantities of ants there was a prevalence of smaller-sized species that could locate, recruit, and dominate the sardine bait traps with greater flexibility in relation to other species. The aggressive behavior of the smaller ants, especially the genus Pheidole, was clearly observed during the experiment, with notable access restrictions to the baits, for larger-sized ants.

Another relevant factor in relation to strong competition between different ant species in search of food lies in the availability of resources found in their habitat. Possibly, the pronounced homogeneity of the environments under analysis may emphasize the competition for food. Due to a lower diversity of resources, these ants may have found, in the baits, precious food sources previously inexistent, which explains such contentious behavior. The experiment demonstrated that the lack of diversified sources of food directly affected the coexistence of organisms.

Improving the methods for collecting ants is a constant concern for myrmecologists, who aim for a more reliable species estimation method, so that they can attain high standards in richness, diversity, and other potential estimates, in order to better understand the environmental characteristics of a given form and compare them with those set by other forms of collection previously defined [32].

For GF, a diversity of 1.471 for the bait technique and 1.202 for pitfall traps was obtained (Figure 4).

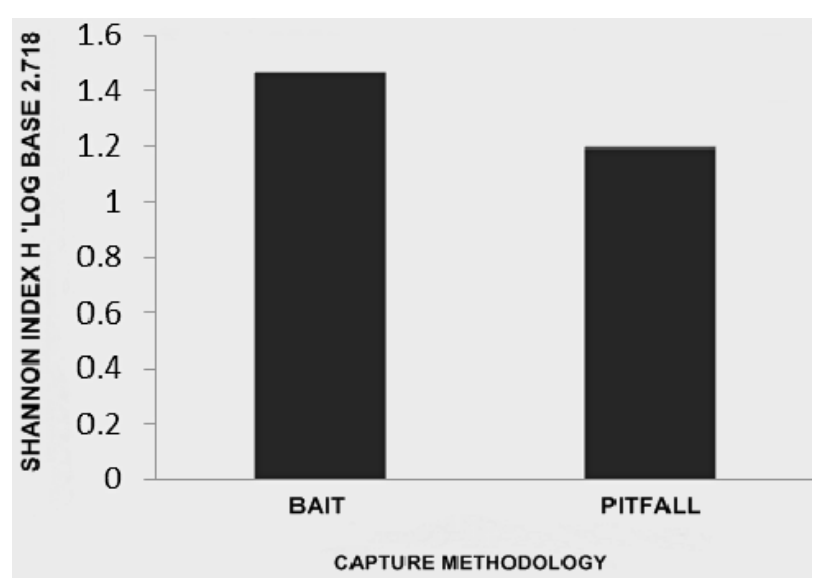

Figure 4. Diversity (GF) calculated by the Shannon index H' Log Base 2.718. Biodiversity Professional Program [21].
It was not possible to observe a wide variation in the diversity found with the bait and trap mechanisms for the GF (Figure 4). A major difference was observed in the sampling methods in the CF (Figure 5) with a 1.407 diversity for sardine traps and 0.781 for pitfall traps (Figure 5).

There are a number of factors that can influence the composition of ants in a region, such as topographical or edaphic conditions, soil exploitation activities for farming or grazing purposes. Such factors probably influenced the distribution of ant species found in the respective collection areas that currently suffer major anthropic influence, mainly due to the creation of a grazing area and a highway, both of these quite near the survey area [41]. Such variations can be explained due to the occurrence of edge effects in the sampled forests [42,43].

\subsection{Rarefaction Analysis and Jackknife 2 Species Richness Estimator}

The rarefaction curve for both gallery forest and ciliary forest appears not to have reached saturation. The estimated and observed species richness was 27.26 and 24 for Gallery Forest, and 31.94 and 23 for Ciliary Forest (Table 2). The Jackknife 2 species richness indicator was employed since, for this survey, a large number of rare species can be identified in both physiognomies $(>1)$, (Figures 6 and 7) and (Table 2).

Evaluating the estimated and observed values, it can be noted that, although the curves did not fully reach saturation (Figure 6), there was a significant accumulation in the number of ant species captured (Richness) in the two forests (GF, CF), since there is a verifiable tendency toward stabilization in the collectors curve. Complete stabilization of the curve in tropical environments can not be considered a simple task. Species richness is a

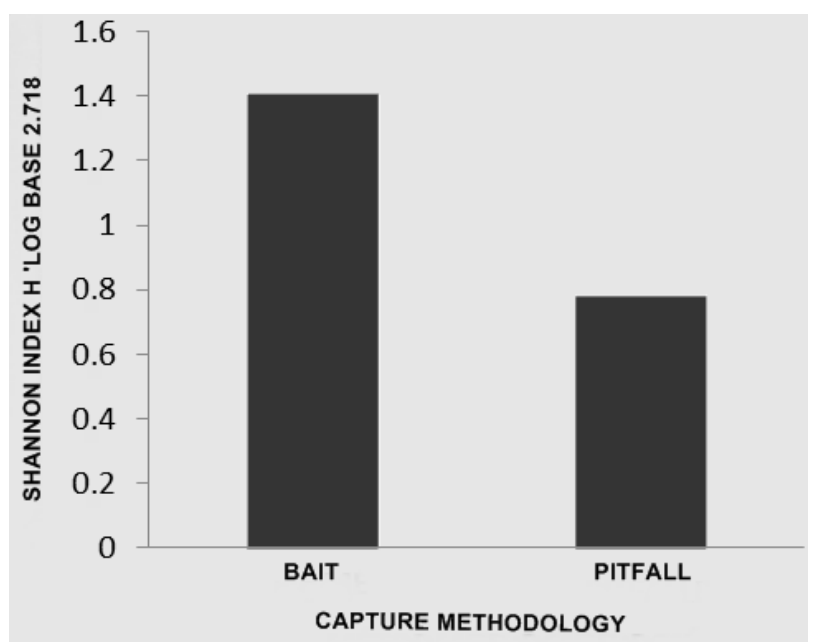

Figure 5. Diversity (CF) calculated by the Shannon index H' Log Base 2.718. Biodiversity Professional Program [21]. 
Tab le 2. Calculations of observed richness (Sobs-Mao Tau), standard deviation (Sobs SD—Mao Tau); estimated richness (Jackknife 2 Mean), standard deviation (Jackknife 2 SD runs) made using the Etimates (Version 8.2.0) program (A—GF; B-CF).

\begin{tabular}{|c|c|c|c|}
\hline \multicolumn{4}{|c|}{ GALLERY FOREST (A) } \\
\hline Sobs (Mao Tau) & Sobs SD (Mao Tau) & Jack 2 Mean & Jack 2 SD (runs) \\
\hline 8 & 1.04 & 0 & 0 \\
\hline 12.94 & 1.18 & 17.59 & 4.94 \\
\hline 16.51 & 1.25 & 26.8 & 5.06 \\
\hline 19.08 & 1.27 & 29.27 & 4.97 \\
\hline 20.89 & 1.25 & 29.85 & 5.23 \\
\hline 22.13 & 1.22 & 28.38 & 5.09 \\
\hline 22.97 & 1.18 & 27.23 & 3.84 \\
\hline 23.56 & 1.16 & 26.72 & 2.83 \\
\hline 24 & 1.16 & 27.26 & 0 \\
\hline \multicolumn{4}{|c|}{ Estimates (Version 8.2.0), Copyright R. K. Colwell: http://viceroy.eeb.uconn.edu/estimates } \\
\hline \multicolumn{4}{|c|}{ Diversity output from input file: Ants gallery forest (August 7, 2013) } \\
\hline \multicolumn{4}{|c|}{ CILIARY FOREST (B) } \\
\hline Sobs (Mao Tau) & Sobs SD (Mao Tau) & Jack 2 Mean & Jack 2 SD (runs) \\
\hline 6.56 & 1.08 & 0 & 0 \\
\hline 10.92 & 1.4 & 14.89 & 4.58 \\
\hline 14.29 & 1.66 & 22.71 & 6.52 \\
\hline 16.85 & 1.82 & 27.73 & 7.02 \\
\hline 18.78 & 1.92 & 28.84 & 7.11 \\
\hline 20.23 & 1.97 & 29.34 & 6.13 \\
\hline 21.33 & 2 & 30.26 & 5.05 \\
\hline 22.22 & 2.04 & 29.99 & 1.83 \\
\hline 23 & 2.1 & 31.94 & 0 \\
\hline \multicolumn{4}{|c|}{ Estimates (Version 8.2.0), Copyright R. K. Colwell: http://viceroy.eeb.uconn.edu/estimates } \\
\hline
\end{tabular}

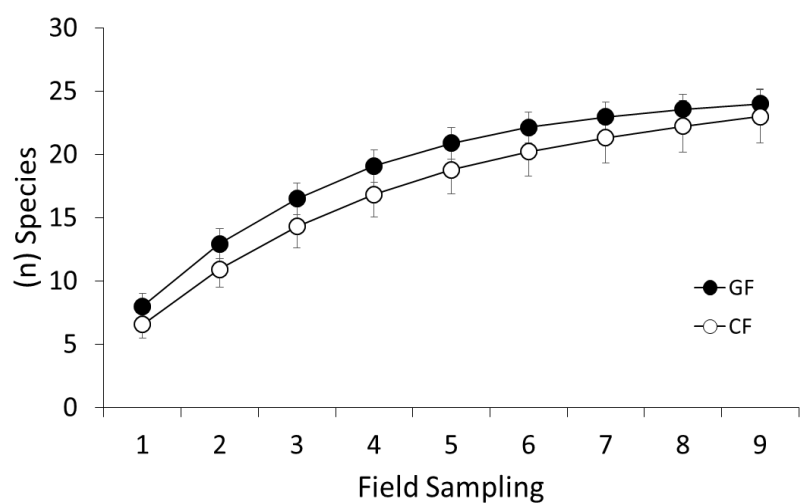

Figure 6. Observed species accumulation curves, considering the three types of collection techniques (pitfall, baited with sardines, and manual collection) by assay, there being 9 samples for each sampling area (GF and CF).

characteristic of paramount importance in a faunistic survey, and is difficult to quantify especially in Tropical Forests that require the use of diversified collection techniques and the study of different niches [44], as were performed in this study.

\section{FINAL CONSIDERATIONS}

There was a satisfactory approximation between estimated richness and observed richness for the study envi-

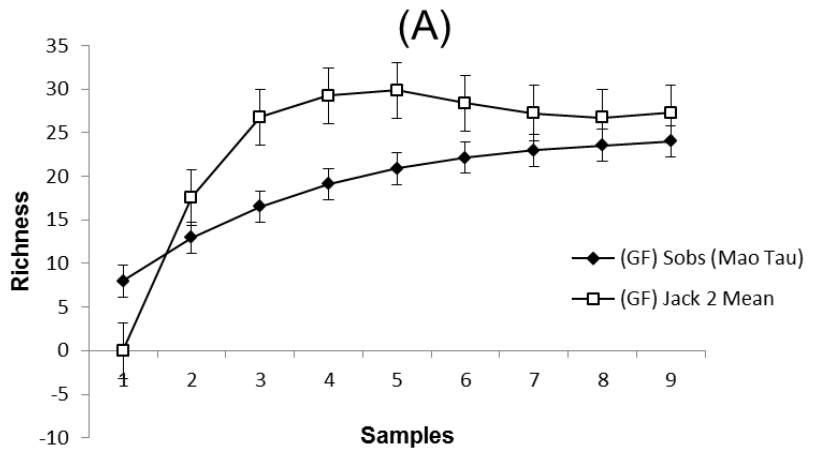

(B)

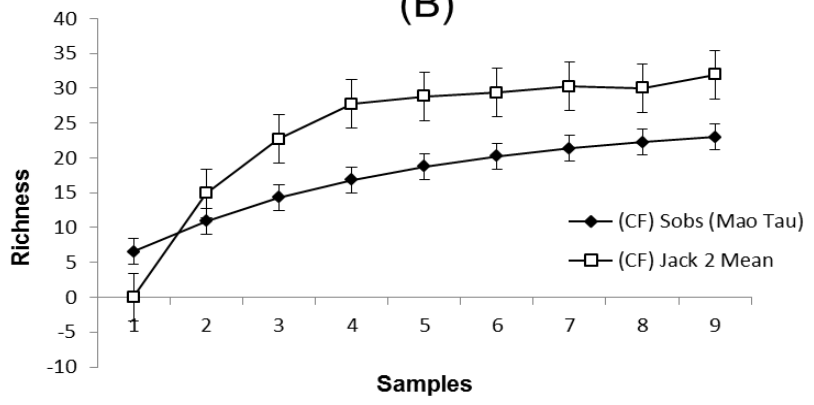

Figure 7. Observed and estimated ant species richness (Mau Tao $\times$ Jackknife 2 Mean) in the set of samples from pitfall-type and sardine bait soil traps, and manual collection at the Douradinho Farm, Quirinopolis, Goiás (Brazil). (A) Gallery Forest, (B) Ciliary Forest. 
ronment. According to the statistical analysis, there was a certain similarity in the faunal diversity of the ants, a fact that can be explained by the structural similarity of the vegetation, such as the presence of plant litter, a characteristic observed in both forests (GF, CF), or even due to the interference to which the environments are subjected. Regarding the effectiveness of the techniques, the sardine baits reached a more representative value, with 25 species collected, compared with 20 from the pitfall traps. Manual collection analysis obtained a richness of 8 species. Given the particularities of each technique, the need to use a wide variety of capture tools is evident in an experiment with ants. The techniques, when used together, complement their restrictions, thus extending the possibility of obtaining a better representation of the ant populations, which allows for better measurement of the action and function of these organisms in a given community.

\section{SPECIAL ACKNOWLEDGEMENTS}

To the owners of the Douradinho Farm, Mr. Tibúrcio Fernandes and Mrs. Maria do Carmo, for their great kindness and consideration during the collection days.

To Dr. Renata Pacheco, biologist at the Social Insect Ecology Laboratory (UFU) for helping with the identification of the ants.

And special thanks to Masters Teacher Wellington Hannibal, for his support during the statistical analysis.

\section{REFERENCES}

[1] Alonso, L.E., Agosti, D., Majer, J.D. and Schultz, T.R. (2000) Biodiversity studies, monitoring, and ants: An overview, In: Ants: Standard Methods for Measuring and Monitoring Biodiversity, Smithsonian Institution Press, Washington, 1-8.

[2] Hughes, L. and Westoby, M. (1990) Removal rates of seeds adapted for dispersal by ants. Ecology, 7, 138-148. http://dx.doi.org/10.2307/1940254

[3] Leal, I.R. and Oliveira, P.S. (2000) Foraging ecology of attine ants in a neotropical savanna: Seasonal use of fungal substrate in the Cerrado vegetation of Brazil. Insectes Sociaux, 47, 376-382. http://dx.doi.org/10.1007/PL00001734

[4] Agosti, D., Majer, J.D., Alonso, L.E. and Schultz, T. (2000) Standard methods for measuring and monitoring biodiversity. Smithsonian Institution Press, Washington.

[5] Oliveira-Filho, A.T. and Ratter, J.A. (2002) Vegetation physiognomies and wood flora of the Cerrado biome. In: Oliveira, P.S. and Marquis, R.J., Eds., The Cerrados of Brazil: Ecology and Natural History of a Neotropical Savanna, Columbia University, New York, 91-120.

[6] Borlaug, N.E. (2002) Feeding a world of 10 billion people: The miracle ahead. In: Bailey, R., Ed., Global Warming and Other Eco-Myths, Competitive Enterprise Institute, Roseville, 29-60.

[7] Ribeiro, J.F. and Walter, B.M.T. (1998) Fitofisionomias do bioma Cerrado. In: Sano, S.M. and Almeida, S.P. Eds., Cerrado: Ambiente e Flora, EMBRAPA-Cerrados, Planaltina, 89-166.

[8] Dias, B.F.S. (1992) Alternativas de desenvolvimento dos Cerrados: Manejo e conservação dos recursos naturais renováveis. Instituto Brasileiro do Meio Ambiente e dos Recursos Naturais Renováveis (Ibama), Fundação PróNatureza (Funatura), Brasília.

[9] Machado, R.B., Ramos, N.M.B., Harris, M.B., Lourival, R. and Aguiar, L.M.S. (2004) Análise de lacunas de proteção da biodiversidade no Cerrado. Anais IV Congresso Brasileiro de Unidades de Conservação, Fundação $\mathrm{O}$ Boticário de Proteção à Natureza, Curitiba, 29-38.

[10] Machado, R.B., Ramos, N.M.B., Pereira, P., Caldas, E., Gonçalves, D., Santos, N., Tabor, K. and Steininger, M. (2004) Estimativas de perda da área do Cerrado brasileiro. Conservation International do Brasil, Brasília.

[11] Alho, C.J.R. (1990) Distribuição da fauna num gradiente de recursos em mosaico. In: Pinto, M.N., Ed., Cerrado: Caracterização, Ocupação e Perspectivas, Universidade de Brasília, Brasília, 205-254.

[12] Conservação Internacional (2005) Hotspots revisitados. www.conservation.org.br/publicacoes/files/HotspotsRevis itados.pdf

[13] Kempf, W.W. (1978) A preliminary zoogeographical analysis of a regional ant fauna in Latin America. Studia Entomologica, 20, 43-62.

[14] Ribas, C.R., Schoereder, J.H., Pic, M. and Soares, S.M. (2003) Tree heterogeneity, resource availability, and larger scale processes regulating arboreal ant species richness. Austral Ecology, 3, 305-314.

[15] Silva, R.R., Brandão, C.R.F. and Silvestre, R. (2004) Similarity between cerrado localities in central and southeastern Brazil based on the dry season bait visitors ant fauna. Studies on Neotropical Fauna and Environment, 39, 191-199. http://dx.doi.org/10.1080/01650520412331271783

[16] Esri (2008) Arcgis 9-ArcMap version 9.3 copyright.

[17] Ambiente Brasil. http://ambientes.ambientebrasil.com.br/natural/clima/clim aclassificacao_dos_climas_do_brasil.html

[18] Discoverlive (2012) http://www.discoverlife.org

[19] Antweb (2012) http://www.antweb.org

[20] Tavares, A.A. (2002) Estimativas da diversidade de formigas (Hymenoptera: Formicidae) de serapilheira em quatro remanescentes de floresta ombrófila densa e uma restinga no Estado de São Paulo, Brasil. Tese (Doutorado), Faculdade de Filosofia, Ciências e Letras de Ribeirão Preto, Universidade de São Paulo.

[21] BioDiversity Professional (1997) The natural history museum \& the Scottish association for Marine science.

[22] Colwell, R.K. (2005) Estimates: Statistical estimation of species richness and shared species from samples. User's guide and application.

http://viceroy.eeb.uconn.edu/estimates/EstimateSPages/E stSUsersGuide/EstimateSUsersGuide.htm

[23] Tavares, A.A., Bispo, P.C. and Zanzini, A.C.S. (2001) 
Comunidades de formigas epigéicas (Hymenoptera, Formicidae) em áreas de Eucalyptus cloeziana F. Muell e de vegetação nativa numa região de cerrado. Revista Brasileira de Entomologia, 45, 251-256.

[24] Brandão, C.R.F. (1990) Systematic revision of the neotropical ant genus Megalomyrmex Forel (Hymenoptera: Formicidae: Myrmicinae), with the description of thirteen new species. Arquivos de Zoologia, 31, 411-481.

[25] Brandão, C.R.F. (2003) Further revisionary studies on the ant genus Megalomyrmex Forel (Hymenoptera: Formicidae: Myrmicinae: Solenopsidini). Papéis Avulsos de Zoologia (São Paulo), 43, 145-159. http://dx.doi.org/10.1590/S0031-10492003000800001

[26] Fonseca, R.C. and Diehl-Fleig, E. (2004) Riqueza de formigas (Hymenoptera, Formicidae) epigéicas em povoamentos de Eucalyptus spp. (Myrtaceae) de diferentes idades no Rio Grande do sul, Brasil. Revista Brasileira de Entomologia, São Paulo, 48, 95-100.

[27] Silva, R.R. and Silvestre, R. (2004) Riqueza da fauna de formigas (Hymenoptera: Formicidae) que habita as camadas superficiais do solo em Seara, Santa Catarina. $\mathrm{Pa}$ péis Avulsos de Zoologia, 44, 11.

[28] Silva, L.B.A. (2006) Composição, riqueza e raridade de espécies de formigas (Hymenoptera: Formicidae) em povoamentos de eucaliptos e mata nativa na Reserva Biológica União/IBAMA, P.34 Dissertação (Mestrado em Ciências Ambientais e Florestais). Instituto de Florestas, Departamento de Ciências Ambientais, Universidade Federal Rural do Rio de Janeiro, Seropédica.

[29] Santos, M.S., Louzada, J.N.C., Dias, N., Zanetti, R., Delabie, J.H.C. and Nascimento, I.C. (2006) Riqueza de formigas (Hymenoptera, Formicidae) da serapilheira em fragmentos de floresta semidecídua da Mata Atlântica na região do Alto do Rio Grande, Brasil. Iheringia, Série Zoológica, 96, 95-101.

[30] Queiroz-Dantas, K.S., Queiroz A.C.M., Neves F.S., ReisJúnior, R. and Fagundes M. (2011) Formigas (Hymenoptera: Formicidae) em diferentes estratos numa região de transição entre os biomas do Cerrado e da Caatinga no norte de Minas Gerais. Biota, 4, 17-31.

[31] Coelho, I.R. and Ribeiro, S.P. (2006) Environment heterogeneity and seasonal effects in ground-dwelling ant (Hymenoptera: Formicidae) assemblages in the Parque Estadual do Rio Doce, MG, Brazil. Neotropical Entomology, 35, 19-29. http://dx.doi.org/10.1590/S1519-566X2006000100004

[32] Olson, D.M. (1991) A comparison of the efficacy of litter sifting and pitfall traps for sampling leaf litter ants (Hymenoptera: Formicidae) in a tropical wet forest. Costa Rica. Biotropica, 23, 166-172. http://dx.doi.org/10.2307/2388302
[33] Delabie, J.H.C., Agosti, D. and Nascimento, I.C. (2000) Litter ant comunities of Brazilian Atlantic rain forest region. In: Agosti, D., Majer, J.D., Alonso, L.E. and Scchultz, T.R., Eds., Sampling Ground-Dwelling Ants: Case Studies from de World's Rain Forests. Bulletin 18, Curtin University School of Environmental Biology, Perth, 1-17.

[34] Silva, R.R. and Lopes, B.C. (1997) Ants (Hymenoptera: Formicidae) from Atlantic rainforest at Santa Catarina Island, Brazil: Two years of sampling. Revista de Biologia Tropical, 45, 1641-1648.

[35] Bruhl, C.A., Mohamed, M. and Linsenmair, K. (1998) Altitudinal distribution of leaf litter ants along a transect in primary forests in Mount Kinabalu, Sabah, Malaysia. Journal of Tropical Ecology, 15, 265-277. http://dx.doi.org/10.1017/S0266467499000802

[36] Silva, R.R. and Silvestre, R. (2000) Diversidade de formigas (Hymenoptera: Formicidae) em Seara, oeste de Santa Catarina. Biotemas, 13, 85-105.

[37] Hölldobler, B. and Wilson, E.O. (1990) The ants. Belknap press of Harvard University, Cambridge, 722.

[38] Bolton, B. (1995) A taxonomic and zoogeographical census of the extant ant taxa. Journal of Natural History, 29, 1037-1056. http://dx.doi.org/10.1080/00222939500770411

[39] Fowler, H.G., Forti, L.C., Brandão, C.R.F., Delabie, J.H.C. and Vasconcelos, H.L. (1991) Ecologia nutricional de formigas. In: Panizzi, A.R. and Parra, J.R.P., Eds., Ecologia Nutricional de Insetos e suas Implicações no Manejo de Pragas, Manole, São Paulo, 131-223.

[40] Romero, H. and Jaffé, K. (1989) A comparison of methods for sampling ants (Hymenoptera: Formicidae) in Savannas. Biotropica, 21, 348-352. http://dx.doi.org/10.2307/2388285

[41] Feener, D.H. and Schupp, E.W. (1998) Effect of treefall gaps on the patchiness and species richness of neotropical ant assemblages. Oecologia, 116, 191-201. http://dx.doi.org/10.1007/s004420050579

[42] Breton, J.L., Chazeau, J. and Joudan, H. (2003) Immediate impacts of invasion by Wammania auropunctata (Hymenoptera: Formicidae) on native litter ant fauna in a New Caledonian rainforest. Austral Ecology, 28, 204-209. http://dx.doi.org/10.1046/j.1442-9993.2003.01266.x

[43] Carvalho, K.S. and Vasconcelos, H.L. (2002) Comunidade de formigas que nidificam em pequenos galhos da serapilheira em floresta da Amazônia Central, Brasil. Revista Brasileira de Entomologia, 46, 115-121.

[44] Longino, J.T., Coddington, J. and Colwell, R.K. (2002) The ant fauna of a tropical rain forest: estimating species richness tree different ways. Ecology, 83, 689-702. 